\title{
Iliac Vessel
}

National Cancer Institute

\section{Source}

National Cancer Institute. Iliac Vessel. NCI Thesaurus. Code C133757.

Any of the branches of the vessels arising from the common iliac artery or vein, located

in the pelvis. 